\title{
How Do Urban Neighbourhoods Impact Parents' Subjective Well-being?
}

\author{
Jaana Poikolainen* \\ Youth Research and Development Centre Juvenia \\ South-Eastern Finland University of Applied Sciences \\ Email: jaana.poikolainen@xamk.fi \\ ${ }^{*}$ corresponding author

\section{Kati Honkanen} \\ The School of Applied Educational Science and Teacher Education \\ University of Eastern Finland, \\ Email: k.honkanen@dnainternet.net
}

\begin{abstract}
Introduction: In this paper, parents' well-being is examined from their subjective point of view of their living experiences in a certain residential area. The subjective viewpoint is relevant as the focus of the research is interlinked with residential areas.
\end{abstract}

Aims: The research aims to determine what meaning parents ascribe to their residential area (suburb or city centre) as a space for physical, social and psychological well-being. It also aims to discover whether there are qualitative differences between the given meanings of parents living in different areas.

Methods: The data were acquired through semi-structured interviews with parents who live in a suburb or the city centre of Lahti, Finland. Data analysis was conducted using abductive thematic analysis.

Results: The results revealed that physical, social and psychological spaces were experienced differently depending on the residential area in question. In parents' narration about the physical space, in both areas the basic services were defined as valuable for well-being. Parents living in the suburb experienced the natural environment as an important source of well-being. When talking about the social space, the parents living in the suburb emphasised social networks and the importance of building well-being bridges in their neighbourhood, unlike the city dwellers. The psychological space was connected to the reputation and security of the residential area. An important well-being factor for all parents was the wellbeing of their children, with an emphasis on the safety of the residential area.

Discussion: Subjective assessments of neighbourhood attributes are more important in explaining neighbourhood satisfaction than any perceived reputation. Parents' ways of thinking and acting in certain residential areas appear to tie in with the social capital that forms social resources. Almost all parents who participated in this research estimated their well-being as rather high, irrespective 
of their socioeconomic status, but the city centre residents rated their well-being even higher.

Keywords: Parents, neighbourhood, subjective well-being, place, space

In this paper, well-being is examined from a subjective point of view based on parents' living experiences in a certain residential area. Parents often think about their neighbourhood context through parenthood (Cuellar, Jones, \& Sterrett, 2015). Using a subjective viewpoint has proved to be relevant when the focus of research is interlinked with residential areas and their meaning to residents (Clark, 2009; Clark \& Lisowski, 2018; Honkanen \& Poikolainen, 2014; Koistinen, Peura-Kapanen, Honkanen, \& Poikolainen, 2017; Permentier, Bolt, \& van Ham, 2011). Well-being is often approached through risks, insecurities, shortcomings and social problems, but a positive, empowering approach is also needed. A positive notion of well-being is based on the strengths and capabilities needed for human growth, especially when facing unpleasant episodes (e.g., Clark \& Lisowski, 2018; Luhmann, Hawkley, \& Cacioppo, 2014; Luhmann, Hofman, Eid, \& Lucas, 2012).

Well-being is based on individual experiences (Kroll, 2011) and therefore subjective well-being (SWB) indicators have been used in research in many countries for decades (e.g., Pontin, Schwannauer, Tai, \& Kinderman, 2013). In these studies, the core idea is to study the respondents' views on, for example, life satisfaction and happiness. Variance can be explained by personal traits and specific life circumstances such as employment, income and meaningful social relationships, which are the factors that have been reported as scoring highly when people feel positive about their well-being (Luhmann, Hawkley, \& Cacioppo, 2014). Background variables are supposed to correlate with subjective well-being, and the statistical conclusions are drawn from these correlations (Diener, Inglehart, \& Tay, 2013; Pontin et al., 2013). However, there is variance in such influences depending on individual differences and coping strategies (Hofman, Eid \& Lucas, 2012).

Well-being is experienced in certain neighbourhoods (Mellander, Florida, \& Stolaric, 2011) and where possible, parents decide where they live with their children. A neighbourhood is a place where everyday life is lived with children and therefore it is an important research context (Cuellar, Jones, \& Sterrett, 2015). A deprived neighbourhood is supposed to lead to negative well-being outcomes (Garvin et al., 2012). Parents experience their well-being uniquely and also assign their own meanings to their residential area as a well-being 
environment (Koistinen et al., 2017). For example, parents attribute different meanings to social resources in their neighbourhood context, and therefore it is reasonable to examine such nuances (Coleman, 1988; Cuellar, Jones, \& Sterrett, 2015; Kleinhans, Priemus, \& Engbersen, 2007). More research is needed on the meaning of a residential area as a well-being environment. Therefore, the research questions are the following: What kind of meanings do parents ascribe to their residential area (suburb or city centre) as a physical, social and psychological well-being space? Are there qualitative differences between the given meanings of parents living in different areas?

\section{Significance of the Residential Area as a Source of Well- being}

During recent years, research has pointed to the effects of the residential area on well-being. It has been stated that geographical or political dimensions and political decisions affect well-being (Bernini, Guizzardi, \& Angelini, 2013). For example, housing policy directs housing choices-where and how citizens live (Rasinkangas, 2013). Of course, during the course of life different issues are important such as income, health and family (e.g., Koistinen, et al., 2017; Margolis \& Myrskyla, 2013).

Suburbs and the lives of their inhabitants have been studied for a few decades in Finland, but so far the research is scant. Often the focus has been on housing preferences in the Helsinki metropolitan area (Kemppainen, Lönnqvist, \& Tuominen, 2014; Vilkama \& Vaattovaara, 2015), place attachment (Koistinen et al., 2017; Seppänen, 2012), social segregation (Rasinkangas, 2013) and the spatial nature of urban well-being (Ala-Mantila, Heinonen, Junnila, \& Saarsalmi, 2018). Lately, the experiences of the middle class living in socioeconomically disadvantaged areas have been in focus in the Helsinki metropolitan area (Vilkama \& Vaattovaara, 2015). Our focus is also on disadvantaged areas, but we concentrate more on the working class or parents who are not working at the moment, and examine how they define the issues that are important to their well-being.

Parents live in different physical, social and psychological spaces, and define the contents and meanings of those according to their own preferences. Parental well-being is shaped by a combination of spaces constructed in different dimensions. The first dimension, physical space, consists of the physical residential area and its services, the transportation network (Cuellar, 
Jones, \& Sterrett, 2015) and the natural environment (Carter \& Horwitz, 2014), for example. The importance of green space usability to the well-being of individuals and communities has been proved (Carter \& Horwitz, 2014; Völker \& Kistemann, 2015), as have the health effects of water, or blue space (Völker \& Kistemann, 2015). Nearby nature appears to "buffer" the effect of a lack of social connectedness on well-being (Cartwright, White, \& Clitherow, 2018) and the presence of nature in cities can support recovery from stress (Taylor, Hahs, \& Hochuli, 2017). The experiences of the physical environment affect wellbeing; for example, unbuilt vacant land is seen as frightening and unattractive (Garvin et al., 2012). Bell, Phoenix, Lovell, and Wheeler (2014) and Ala-Mantila, Heinonen, Junnila, and Saarsalmi (2018) have stated that we still know relatively little about the meaning of the local environment for well-being as defined by the inhabitants. The key idea in this article is that parents define for themselves which issues in their residential area are meaningful for their wellbeing.

The second dimension, the social space, refers to how inhabitants value their social relationships in the residential area (Runge, 2018). A neighbourhood is a potential space for creating social relationships, if these are seen as valuable (Benson, 2014; Coleman, 1988). The place of residence and family stage play a role in the style of community involvement (Hofmaister \& Edgell, 2015; Strange, Fisher, Howat, \& Wood, 2014). Social resources are linked to the social climate of the neighbourhood, as people generally place importance on the feeling of belonging to a group and place (Strange et al., 2014).

When studying the connection between social relationships and well-being (Honkanen \& Poikolainen, 2014), we adopt the classical division of social capital defined by Coleman (1988; Kleinhans et al., 2007), who divides social capital into different dimensions according to the form and solidity of the social relations. These relations in certain social spaces in certain neighbourhoods are an important interest of this study. The first dimension is bonding social capital, which refers to a rather tight-knit group consisting of, for example, family members, relatives and close friends. This capital produces the feeling of solidarity, as the members involved in the relationships share similar norms. The second dimension is bridging social capital, which is built between different groups, for example, friends and neighbours. The members of these groups often have a similar background in terms of social status, beliefs and appreciation. The third dimension is linking social capital, which operates vertically, combining bonding and bridging capital. The divisions are used here 
to describe the importance of parents' social networks to their well-being in certain residential areas. For example, Clark and Lisowski (2018) showed in their study that social capital has strong associations with subjective well-being when the individuals evaluated their community and neighbourhood relationships. Also, local social capital is strongly associated with place satisfaction and modestly associated with life satisfaction.

The third dimension, the psychological space, relates to how inhabitants feel about living in the neighbourhood, and the issues that are important for wellbeing in that neighbourhood (Cuellar, Jones, \& Sterrett, 2015), such as whether they define the area as a safe place to live (Kemppainen et al., 2014). Unbuilt vacant land is a problem for the economy of many cities, and can be a frightening place according to inhabitants' opinions, as Garvin et al. (2012) have shown.

\section{Research Context, Data and Analysis}

\section{Suburb and City Centre}

The research contexts of this study are the Liipola suburb and the city centre of Lahti, which is situated in southern Finland, $100 \mathrm{~km}$ from the capital, Helsinki. The suburb is located around $3 \mathrm{~km}$ from the city centre.

Finland's urbanisation took place between the 1960s and 1970s. The suburbs were created as a solution to the needs of industrialised society, with apartments built in areas near factories with good public transport connections (Kortteinen, 1982). The number of industrial jobs has decreased, and the majority of the inhabitants of Liipola are now older people, while the number of families with children has decreased (Seppänen, Haapola, Puolakka, \& Tiilikainen, 2012). In 2014, when the data were gathered, the population exceeded 4,400 (Tilda, 2014), and most people were living in houses built during the 1970s (Seppänen et al., 2012). Services in the area have gradually reduced, but at that time there was still a grocery store, a library and a church hall. Furthermore, there was a daycare centre and grades one to four at the comprehensive school. The education level of the inhabitants was significantly lower than the average level of the city residents; the employment rate was also much lower than the average in Lahti (Tilda, 2014). The reputation of the suburb has been poor (Seppänen et al., 2012). 
Around 15,500 people live in the city centre, but mobility is constant. The densely populated area consists mainly of new and older blocks of flats, but there are also a few parks. All services are easily reachable by foot, such as schools, shops, malls and healthcare (Honkanen \& Poikolainen, 2014; Koistinen et al., 2017). Most of the interviewed parents had lived in Lahti before moving to their current neighbourhood. All of the families had lived in the residential area for at least two months, with some having lived there for 20 years. Most had lived in the area for several years, and some had even been born there. Eight interviewees lived in the suburb and seven in the city centre. The aim was to reach parents with different socioeconomic positions. We recruited the interviewed parents, 13 mothers and two fathers, from schools' parental evenings, a settlement house and using the snowball method. We tried to reach more fathers, but we did not succeed. Earlier studies have also shown that fathers are not so interested in participating in this kind of research (e.g., Gabb, 2010).

Three parents were immigrants from Russia, Egypt and Thailand, while the rest were native Finnish. The language spoken at home was Finnish for 11 parents; the other languages were Russian, Arabic and Thai. Most interviewees (10/15) were homeowners. Most parents (10/15) had vocational or basic education as the highest education level: university (1), polytechnic education (4), vocational (8) and basic education (2). Their labour market positions were: working (6), (unemployed) housewife (4), part-time work (2), entrepreneur (1), student (1) and disability pension (1). Four of the highly educated parents were either retired or housewives. The basic statistics of the residential areas and their inhabitants are presented in Table 1.

The parents were 29 to 60 years old and the children who still lived at home varied in age from 1 to 14 . The interviewed parents had altogether 32 children living at home. The number of children per household were: parents $3,4,5,10$ and 12 (1), parents 8, 13, 15 and 18 (2), parents 6, 7, 9, 11 and 17 (3) and parent 2 (4) (parents 1 and 14 no longer had children living at home). The aim was to capture the thoughts of those parents whose children lived at home. Eleven of the parents were in a relationship, while four lived alone with their children.

\begin{tabular}{|l|l|l|l|l|}
\hline & Suburb & $\begin{array}{l}\text { Year of } \\
\text { statistics }\end{array}$ & $\begin{array}{l}\text { City } \\
\text { centre }\end{array}$ & $\begin{array}{l}\text { Year of } \\
\text { statistics }\end{array}$ \\
\hline Inhabitants N & 4,419 & 2014 & 15,482 & 2014 \\
\hline
\end{tabular}




\begin{tabular}{|c|c|c|c|c|}
\hline $\begin{array}{l}\text { - Families } \mathrm{N} \\
\text { - Families with children } \%\end{array}$ & $\begin{array}{l}1,099 \\
49 \\
\end{array}$ & $\begin{array}{l}2014 \\
2014\end{array}$ & $\begin{array}{l}3,441 \\
30\end{array}$ & $\begin{array}{l}2014 \\
2014 \\
\end{array}$ \\
\hline Education (only basic) \% & 43.3 & 2013 & 31 & 2013 \\
\hline $\begin{array}{l}\text { Native language Finnish } \\
\%\end{array}$ & 86 & 2014 & 97 & 2014 \\
\hline Unemployed \% & 30 & 2012 & 7.8 & 2013 \\
\hline $\begin{array}{l}\text { Block of flats } \mathrm{N} \\
\%\end{array}$ & $\begin{array}{l}2,764 \\
97.3\end{array}$ & 2014 & $\begin{array}{l}12,293 \\
94\end{array}$ & 2014 \\
\hline Homeowner \% & 31.8 & 2013 & 34 & 2013 \\
\hline Rental apartment \% & 62.5 & 2013 & 49 & 2013 \\
\hline
\end{tabular}

Table 1: Statistics of the Suburb and City Centre. (Source: Tilda, 2015; Statistics Finland, 2015a)

\section{Data and Analysis}

The research interviews were conducted using a thematic interview form. The basic themes were well-being in the physical, social and psychological spaces (Carter \& Horwitz, 2014; Cuellar, Jones, \& Sterrett, 2015; Völker \& Kistemann, 2015), which framed the conversation but did not direct it. The form of the interview was constructed based on earlier research; therefore, familiarity with it was a precondition for the interviewer to be able to lead the themed interview according to the interviewee's answers (Madill, 2011; Roulston, 2011). The parents used their own concepts, and also brought their own significant experience to the discussion. In addition to background questions, an interview form usually involves basic themes and, if necessary, supplementary questions can be used to assist in the completion of the interview (Roulston, 2011). The interview extracts were translated from Finnish into English for this article. The semi-structured interview data consist of knowledge about the factors significant to the parents from the point of view of their own well-being and in relation to where they live. The aim was to be sensitive to parents' stories. Open questions were used such as, 'If you think about your neighbourhood, which issues are important to you?' and 'What kind of meaning does the residential area have for your well-being?' The thematic interview form also involved a figurative (ladder) well-being scale (1-10), which was used as a tool to stimulate discussion and get general information about the subjective well-being of parents.

The more familiar the interview environment is to the interviewee, the more natural the interview situation becomes (Madill, 2011). Therefore, the interviews were performed in places that were most suitable for the parents, such as 
workplaces, cafés and researchers' offices. The interviews took an hour each on average, and the transcribed data corpus takes up 219 pages (Calibri, $12 \mathrm{pt}$ font, single line spacing).

The recorded interviews were analysed using thematic analysis, a method that provides useful tools for organising interview data without losing the core meaning (Vaismoradi et al., 2013). The analysis followed an abductive form. According to Gläser and Laudel (2013), the basic idea of coding interview data is that the transcribed text material is marked according to codes, which can be, for example, keywords or sentences that indicate the occurrence of the information in separate segments of the text.

First, the data of the interview were classified according to the well-being dimensions: physical, social and psychological spaces. The second step was to analyse the contents and themes of the dimensions, and the third step was to find out the meanings the parents attributed to the themes when talking with the researchers. During the third phase, a thematic map was generated and the designation of the themes and interpretation were re-evaluated (Vaismoradi et al., 2013). The examination focused first on the parents living in the suburb, and after that, the researchers analysed whether there were differences between this group and the parents living in the city centre.

Research ethics were addressed during the entire process according to scientific guidelines. The anonymity of the respondents was guaranteed following the general rules and best practices of research ethics, as well as national laws and policies (see Carusi \& Jirotka, 2009). We committed to complying with responsible research conduct and adhering to the guidelines of the Finnish Advisory Board on Research Integrity (2016). All the participants were informed about the research and its purpose. Because of the sample size of this research, instead of the generalisation of the research results, the portability of experiences can be used, meaning that there is possible compatibility with previous studies in different contexts (Metteri, 2012). By comparing results, the interpretations of the data can be confirmed, or it can be stated that something new has been found. In qualitative research, generalisability is not concerned with the collection of representative data; instead, the focus is on the researcher's analysis and interpretation of contexts (Delmar, 2010). 


\section{Findings}

The factors supporting the well-being of parents in the residential area were divided into three dimensions according to the themes (Table 2). The first theme was physical space, which the parents defined as the availability of basic services and the importance of the natural environment. The second theme was social space, which indicated parents' valuation of the balance between privacy and communality. The third theme was psychological space, which to the parents meant a safe environment for children, an area with a good reputation and the possibility of choosing a residential area.

The residential area as a well-being space was defined differently depending on where the interviewed parents live. Inhabitants of the suburb valued sufficient services and the natural environment that surrounds their neighbourhood. The natural environment was an important well-being factor for many parents; they appreciated good outdoor recreation possibilities in the immediate natural environment. The parents living in the city centre appreciated the ease of mobility, nearby services and available hobbies. While the parents living in the suburb appreciated communality, it was avoided in the city centre. Those living in the suburb mainly estimated their well-being as lower than those living in the city centre.

\begin{tabular}{|c|c|c|c|c|}
\hline $\begin{array}{l}\text { Residential } \\
\text { area }\end{array}$ & $\begin{array}{l}\text { Physical } \\
\text { space }\end{array}$ & $\begin{array}{l}\text { Social } \\
\text { space }\end{array}$ & $\begin{array}{l}\text { Psychological } \\
\text { space }\end{array}$ & $\begin{array}{l}\text { Subjective } \\
\text { well-being }\end{array}$ \\
\hline Suburb & $\begin{array}{l}\text { Sufficient } \\
\text { basic } \\
\text { services, } \\
\text { area } \\
\text { surrounded } \\
\text { by natural } \\
\text { environment } \\
\text { and easy } \\
\text { habitation }\end{array}$ & $\begin{array}{l}\text { Large } \\
\text { bonding } \\
\text { resources } \\
\text { are strong, } \\
\text { more } \\
\text { bridging } \\
\text { communality } \\
\text { is hoped for }\end{array}$ & $\begin{array}{l}\text { Better } \\
\text { reputation and } \\
\text { security are } \\
\text { hoped for }\end{array}$ & $\begin{array}{l}10 \text { [2], } 5 \text { [3], } \\
8-9 \text { [7], } 8 \text { [8], } \\
7 \text { [9], - [12], } \\
- \text { [17], } 7 \text { [18] }\end{array}$ \\
\hline City centre & $\begin{array}{l}\text { Good } \\
\text { services, } \\
\text { enjoyable } \\
\text { natural } \\
\text { environment } \\
\text { sites within } \\
\text { the city }\end{array}$ & $\begin{array}{l}\text { Restricted } \\
\text { bonding } \\
\text { resources } \\
\text { are strong, } \\
\text { communality } \\
\text { is avoided }\end{array}$ & $\begin{array}{l}\text { Urban } \\
\text { environment } \\
\text { with adequate } \\
\text { security and } \\
\text { reputation }\end{array}$ & $\begin{array}{l}9[4], 9-10 \\
{[5],} \\
9[6], 9[10], \\
9[11], 9 \\
{[13],} \\
-[15]\end{array}$ \\
\hline
\end{tabular}

Table 2: Physical, Social and Psychological Spaces and Well-being 


\title{
Physical Space: Services, the Natural Environment and Housing
}

Sufficient services are available for parents living in the suburb, such as a grocery shop, and many social services, such as a child welfare clinic, are located nearby. As previously mentioned, services are part of physical space (Cuellar, Jones, \& Sterrett, 2015). The parents were satisfied with the services, which were, in their opinion, reachable by walking or using public transportation. Koistinen et al. (2017) found that family-centred residents appreciate services above all, such as social and health services, their availability and quality.

The parents discussed many issues regarding the well-being of their children. The area was criticised as being depressing due to its external reputation, suggesting an idea of a reputation without an individual experience. In general, the parents were satisfied with the suburb and had no plans to move out. The natural environment and good facilities for outdoor recreation, both for adults and children, were seen as attractive. According to previous research, an urban, green, natural environment is an important factor of well-being (see Carter \& Horwitz, 2014; Cartwright, White, \& Clitherow, 2018; Honkanen \& Poikolainen, 2014; Völker \& Kistemann, 2015).

\begin{abstract}
We had a dream that we would buy a bigger flat than those in our previous apartment building. We wanted to live in this house because we like it that much. I like to exercise, and here we have good roads and trails, and there are good places for children to play. It is very easy to be outdoors with them. We do not have to go near the road if we do not want to. We can walk through the forest. So I like this very much. (Mother 2, four children8, 6, 3 and 1 year old, polytechnic bachelor's degree, housewife, suburb, swb 10)
\end{abstract}

Parents living in the city centre valued easily accessible services and versatile possibilities for hobbies. The inhabitants living in a block of flats in the city centre particularly appreciated the handiness of living near services. In addition, the natural environment located nearby was appreciated, although the parents emphasised its significance for well-being less than the parents living in the suburb.

Everything is near in Lahti-forests and outdoor recreation areas. We have to go only 500 metres and we can ski and skate. There is a lot of everything for younger children, such as playgrounds. And there is a library, which has been very much in use, and a theatre; these are the most important ones. (Mother 4, one child-13 year old, polytechnic education, secretary, city centre, swb 9)

Many parents living in the suburb stated that they were thus far satisfied with the range of services, but if the school—which had already been downsized- 
and the shop closed, this would cause difficulties in everyday life. Greater significance was placed on staying in the residential area because of the quality of the area than, for example, because of economic factors. The most important factors were the beauty of the area and the physical environment (see also Mellander et al., 2011). Nature has the potential to support well-being, especially in urban environments (Taylor et al., 2018). In the city centre there are several schools and all the necessary services, and the parents were satisfied with those.

\section{Social Space: Resources and Communality}

Communality and social resources were appreciated by parents living in the suburb. The parents participated in events that support communality, and they found it important to have manifold friend and kin networks. Communality was mostly supported by people who shared similar life situations-parents who had either created bonding or bridging capital or were working towards doing so. The uniting factor was children; parents found it easier to interact with people who shared the same norms (see also Hofmeister \& Edgell, 2015; Kleinhans et al., 2007).

\footnotetext{
Well, we have regular friends who visit the place [playground]. I think it was me who suggested, 'What if we do some voluntary work and take rakes and gather the garbage and afterwards have juice?' It is so fun, even in the children's opinion. (Mother 3 , one child-4 year old, comprehensive school, cleaner, suburb, swb 5)
}

A vital entrenching factor was that the inhabitants could build and maintain friendships in the area (Mellander et al., 2011). Active inhabitants wanted to invest time and effort for the sake of the neighbourhood.

Some parents said they wanted to keep their distance from neighbours, and instead continue with active, pre-established friendships. As Kleinhans et al. (2007) have noted, newcomers in a neighbourhood can be more active in searching for social networks than long-term residents. Some parents mentioned that forming and sustaining social networks had proved difficult, even though they wished to participate in the social networks of the neighbourhood. However, the concrete methods and actions required to strengthen communality were often missing.

The parents also discussed cultural differences; for example, native Finnish people are used to exercising outdoors, but parents from many other cultures are used to staying indoors. There are no tempting communal meeting points, 
with the exception of playgrounds. However, inhabitants born outside Finland liked their Finnish neighbours, and said that they received help when needed. A multicultural neighbourhood was seen as a positive.

Well, Finnish people are very friendly. My neighbour has many children and they talk with us; our children exercise outdoors and walk to school together. (Mother 9, three children-13, and two 9 year olds, polytechnic bachelor's degree, unemployed, suburb, swb 7)

Despite the poor reputation of the residential area, it was described as a good neighbourhood-one that is approving and tolerant. The social environment was seen as responsive, with children who could be defined as "different" easily able to make friends.

\begin{abstract}
Where we lived previously, Aku was in kindergarten half the day, and he never got any birthday invitations. We tried every children's club, but because he could not speak, no one invited us. It was terrible; we were very lonely. And when we moved here, Aku fitted in at the kindergarten just like that. He made friends immediately; they did not mind his disabilities and they asked him to their homes to play. (Mother 7, five children-10, 8 and 6 year old, and two children aged 19 and 21 who do not live at home, vocational education, housewife, suburb, swb 8-9)
\end{abstract}

The social environment has become individualised in the city centre, and there are no collective obligations. The parents living in the apartment block purposefully kept their distance from their neighbours. They did not feel the need for communality, as those living in the suburb did, but they were committed to keeping in touch with relatives living near or far. Bonding capital was linked only to relatives; there was no room for others.

Unfortunately, there are people who live here who make a lot of trouble. As my uncle used to say, the neighbours are only for greeting. But oh well, we get along and we used to participate in voluntary work, but nowadays the maintenance man takes care of that too. (Mother 4, one child-13 year old, polytechnic education, secretary, city centre, swb 9)

Those parents living in terraced or detached houses took care of their own regional communality, although there were also territorial battles related to privacy.

\footnotetext{
We have had some disagreements with the neighbour; he has been against everything. We have even been to court. (Father 15, two children-14 and 12 year old, vocational education, entrepreneur, city centre, no swb)
}

Social space was regarded as positive for the children living in the suburb. They have friends who live in the same area and meet them, among other places, at 
an adventure playground. The children's social environment was experienced as pluralistic and tolerant of differences. Most of the parents have connections to other parents in the residential area and the community was appreciated. In terms of developing the area, there was a feeling that there is a need to increase communality.

\title{
Psychological Space: Reputation and Security
}

The poor reputation of the suburb appears to matter little to almost all parents (see also Garvin et al., 2012; Permentier et al., 2011). However, a clear division between better and poorer areas, based on street addresses, was expressed. The geographically defined lower part of the suburb was characterised as peaceful, while the upper area was defined as a place where parents do not willingly walk around with their children. This division is maintained by the parents using the playground of the area with the better reputation. Feelings of insecurity with regard to surroundings impacted the parents' feelings of wellbeing, while the behaviour of some intoxicated people had driven away potential customers from the local shopping centre. Parents found the environment to be unsuitable for children, as these drinkers are negative role models for children.

\begin{abstract}
This [part of the suburb] is a very good district. My experiences are limited to down here and halfway to the hill, but overall I would say this is a very good place for families with children. I do not want to go up the hill when it is dark, and I do not find the surroundings of the shopping centre safe. The customers of the bar make me shudder. It does not feel safe with the children. So we do not visit the area around the shopping centre much. (Mother 3, one child-4 year old, comprehensive school, cleaner, suburb, swb 5)
\end{abstract}

Most of the parents had not experienced criminal activity that had targeted their homes or belongings in the neighbourhood. The few who had did not view it as a serious problem. In the city centre, the psychological environment was described as quite secure, but the parents set strict limits on their children's walks in the evenings.

During the daytime, I feel that walking is totally safe, as there are so many people walking. When it is darker, we do not let the children walk home from friends' houses. We do not trust that it would be safe. We strive to pick them up or meet them. (Mother 6, three children-13, 8 and 4 year old, polytechnic bachelor's degree, salesperson, city centre, swb 9)

The parents also tried to protect their children from negative temptations. The mall, which is located in the city centre, was defined as a negative environment for children and young people. Because of the high crime rate, the city has been 
called the 'Chicago of Finland'. However, the parents living in the city centre did not find that the city's reputation matches its reality.

\begin{abstract}
When we moved here in 1994, people asked why we were moving to the criminal city, and I wondered what they meant. In the 1980s, the city had a reputation of being like Chicago, but the crimes were solved very well. Really, if we consider the statistics, there is crime in other places too. For some reason, the city got that reputation. (Mother 4 , one child-13 year old, polytechnic education, secretary, city centre, swb 9)
\end{abstract}

The reputation of the area was significant for living satisfaction, and thus also for well-being (see Permentier et al., 2011). Kullberg et al. (2010) found that residents' perception of area reputation was strongly associated with environmental well-being; however, residents expressed their happiness about living in their dwelling, irrespective of area. An area's reputation is based on historical events and it changes slowly even if, for example, the physical conditions are altered through renovation work or other innovations.

With regard to psychological space, the reputation of the suburb was significant, especially from the point of view of feeling safe when walking in the area. The women discussed feelings of insecurity (see Kemppainen et al., 2014). The parents who live in the suburb were generally attached to the area despite its reputation. According to them, the reputation was created years or decades ago, and is not valid anymore. The willingness to move was not strong, except if the current apartment became too small for the needs of the family.

\title{
Discussion and Conclusion
}

Welfare-state regimes differ between countries and regions in terms of how they take care of social inequality (Samuel \& Hadjar, 2015). In Europe, there has been increasing debate about the rising differences between inhabitants' subjective well-being and living environments. Neighbourhood has an important meaning in life satisfaction (Clark \& Lisowski, 2018). In Finland, similar results have recently been reported. The well-being of the Finnish population is examined by The National Institute for Health and Welfare in annual reviews. The latest review shows that there are clear differences between the various population groups in terms of well-being and neighbourhood (see IImarinen, Kauppinen, \& Karvonen, 2019). In Finland, over the last 20 years, the disadvantage has begun to accumulate in some areas, and there are several areas of the metropolis where the number of unemployed and low income households has grown (Vaattovaara \& Kortteinen, 2012, 2015). Almost all the 
parents who participated in this research estimated their well-being as rather high, irrespective of their socioeconomic status, but the city centre residents rated their well-being even higher. However, we are aware that recruiting and interviewing more fathers could present a different set of experiences and challenges compared to those of the mothers.

For parents' residential well-being, there were three important themes or topics: services, natural environment and housing, social resources and communality, and neighbourhood reputation and security.

In both the suburb and the city centre, the parents often rated their residential area and its significance for well-being from the point of view of their children's growth environment. The family was considered a protective factor if the neighbourhood was seen as unsheltered. The interviewees who live in the suburb had clearly mentally bound themselves to their residential area despite the criticism that it receives. The safety and peacefulness of the residential area were considered important for well-being, irrespective of the dwelling place. No one was considering moving from their residential area, as they were satisfied. Permentier et al. (2011) found that subjective assessments of neighbourhood attributes are more important in explaining neighbourhood satisfaction than any perceived reputation.

Parents use places for different reasons and purposes. Urban places are set aside for certain activities and furnished with spatial borders, which are implicit structures of power (Dean, 1999). In the suburb there are no places for, for example, the disadvantaged population, so they linger in public places that families with children now avoid as far as possible, as a few of the interviewed parents mentioned. There is a need for spaces for all citizens without segregation (see Honkanen \& Poikolainen, 2014), especially in the suburb.

Even though the suburb largely became their place of residence for economic reasons, the parents adapted to the residential environment and, despite criticising it, emphasised the strengths of the area more strongly than its weaknesses. All of the interviewed parents stated that they had freely chosen where they live and their type of housing. They did not point out any particular reason to move out, such as to gain supplementary social capital for their children. The reasons for living in a certain area were often practical, but it was possible to identify a relationship between well-being and the residential area. People's valuations depended on individual differences, such as their personality, cultural values and other factors (see also Diener et al., 2013). 
The parents living in the suburb were satisfied with the services on offer, which they felt were accessible by walking or using public transport. Parents mentioned the importance of green space for their well-being, as has been noted in earlier studies (Carter \& Horwitz, 2014; Völker \& Kistemann, 2015).

Parents' ways of thinking and acting in certain residential areas appear to tie in with the social capital that forms social resources. Social capital is also associated with both place satisfaction and life satisfaction (see Clark \& Lisowski, 2018). The parents living in the suburb enthusiastically talked about the importance of the social network and the need for communality, but the activities, especially those designed to strengthen communality, varied. Bridging capital was more important for parents living in the suburb. There is a need for opportunities to interact (see Strange et al., 2014). Some of those living in the suburb were in need of tighter communality. The concrete methods and means of adding to the communality and building social bridges between inhabitants are missing, despite continued attempts to develop them by the communal developers of the city.

As Hofmaister and Edgell (2015) found, the place of residence and family stage play a role in the style of involvement in the community. Parents living in the suburb with small children created social networks, for example, by using the local settlement house. Parents of older children did not have the same aspiration for communality, and this could be because of the older children's ability to network more independently. Social status and its creation did not seem to be important, contrary to, for example, Benson's (2014) results. Of course, people tend to understate this kind of factor when talking about preferences. Some parents living in the suburb defined the strict borders of their neighbourhood; they outlined some parts of the area that they believed were home to people with social problems. They did not construct a class division, as the middle-class participants in Benson's (2014) research did, but there was a clearly defined attitude: some people are like us and others are not like us. The residents of the suburb, unlike the city dwellers, did not construct distinctions according to the social statuses of 'us' and 'them'.

There have been several attempts to develop residential areas to be more inhabitant-friendly, and such development projects have also been a focus in other European countries, as Wouter et al. (2009) report. Therefore, the local decision makers and designers of residential areas need information about the factors that increase feelings of well-being in different areas. How do the 
satisfaction and dissatisfaction of inhabitants construct well-being? By studying subjective factors and gaining knowledge about the issues that stimulate inhabitants' well-being and satisfaction, it is possible to develop better residential areas (Bernini et al., 2013). Subjective indicators that describe satisfaction offer a view of people's experiences, both positive and negative, which matters in society (Diener et al., 2013). The results of our research highlight that the meanings parents attribute to their residential area as a physical, social and psychological well-being space reveal valuable knowledge that cannot be obtained through merely examining residential areas according to socioeconomic indicators. It is important to be aware of parents' ways of thinking; for example, how mental bonds to residential areas are constructed and how residential areas affect subjective well-being in many positive ways.

\section{Author Note}

This research was supported by the Housing Finance and Development Centre of Finland [Grant 8987/828/13] and University of Helsinki Centre for Continuing Education $\mathrm{HY}+$

\section{References}

Adler, N., \& Steward, J. (2007). The MacArthur Scale of subjective social status. Retrieved from http://www.macses.ucsf.edu/research/psychosocial/subjective.php

Ala-Mantila, S., Heinonen, J., Junnila, S., \& Saarsalmi, P. (2018). Spatial nature of urban well-being. $\quad$ Regional Studies, 52(7), 959-973 https://doi.org/10.1080/00343404.2017.1360485

Bell, S., Phoenix, C., Lovell, R., \& Wheeler, B. (2014). Green space, health and wellbeing: Making space for individual agency. Health \& Space, 30, 287-292. https://doi.org/10.1016/j.healthplace.2014.10.005

Benson, M. (2014). Trajectories of middle-class belonging: The dynamics of place attachment and classed identities. Urban Studies, 51(14), 3097-3112. https://doi.org/10.1177/0042098013516522

Bernini, C., Guizzardi, A., \& Angelini, G. (2013). DEA-like model and common weights approach for the construction of a subjective community well-being indicator. Social Indicators Research, 114(2), 405-424. https://doi.org/10.1007/s11205$\underline{012-0152-3}$

Carter, M., \& Horwitz, P. (2014). Beyond proximity: The importance of green space useability to self-reported health. EcoHealth, 11(3), 322-332. https://doi.org/10.1007/s10393-014-0952-9

Carusi, A., \& Jirotka, M. (2009). From data archive to ethical labyrint. Qualitative Research, 9(3), 285-298. https://doi.org/10.1177/1468794109105032 
Cartwright, B., White, M., \& Clitherow, T. (2018). Nearby nature 'buffers' the effect of low social connectedness on adult subjective wellbeing over the last 7 days. International Journal of Environmental Research and Public Health, 15(6), 1238. https://doi.org/10.3390/ijerph15061238

Clark, A. (2009). Moving through deprived neighbourhoods. Population, Space and Place, 15(6), 523-533. https://doi.org/10.1002/psp.529

Clark, W., \& Lisowski, W. (2018). Wellbeing across individuals and places: How much does social capital matter? Journal of Population Research, 35(3), 217-236. https://doi.org/10.1007/s12546-018-9207-x

Coleman, J. (1988). Social capital in the creation of human capital. American Journal of Sociology, 94, 95-120. https://doi.org/10.1086/228943

Cuellar, J., Jones, D., \& Sterrett, E. (2015). Examining parenting in the neighbourhood context: A review. Journal of Child \& Family Studies 24(1), 195-219. https://doi.org/10.1007/s10826-013-9826-y

Dean, M. (1999). Governmentality. Power and rule in modern society. London: Sage.

Delmar, C. (2010). "Generalizability" as recognition: Reflections on a foundational problem in qualitative research. Qualitative Studies, 1(2), 115-128. https://doi.org/10.7146/qs.v1i2.3828

Diener, E., Inglehart, R., \& Tay, L. (2013). Theory and validity of life satisfaction scales. Social Indicators Research, 112(3), 497-527. https://doi.org/10.1007/s11205012-0076-y

Finnish Advisory Board on Research Integrity. (2016). Retrieved from http://www.macses.ucsf.edu/research/psychosocial/subjective.phphttp://www.te nk.fi/en/frontpage

Gabb, J. (2010). Home truths: Ethical issues in family research. Qualitative Research, 10(4), 461-478. https://doi.org/10.1177/1468794110366807

Garvin, E., Branas, C., Keddem, S., Sellmann, J., \& Cannuscio, C. (2013). More than just an eyesore: Local insights and solutions on vacant land and urban health. Journal of Urban Health, 90(3), 412-426. https://doi.org/10.1007/s11524-012$\underline{9782-7}$

Gläser, J., \& Laudel, G. (2013). Life with and without coding: Two methods for earlystage data analysis in qualitative research aiming at causal explanations. Forum: Qualitative Social Research, 14(2). Retrieved from http://nbnresolving.de/urn:nbn:de:0114-fqs 130254

Hofmeister, H., \& Edgell, P. (2015). The relevance of place and family stage for styles of community involvement. Community, Work and Family, 18(1), 58-78. https://doi.org/10.1080/13668803.2014.939142

Honkanen, K., \& Poikolainen, J. (2014). Asuinalueet lapsiperheiden vanhempien hyvinvointiympäristöinä - Subjektiivinen näkökulma [Residential areas as parents' well-being environments - Subjective viewpoint]. Yhteiskuntapolitiikka [Social Policy], 79(6), 679-687.

IImarinen, K., Kauppinen, T., \& Karvonen, S. (2019). Asuinolot ja niiden alueellinen vaihtelu. [Living conditions and regional variation]. In L. Kestilä \& S. Karvonen (Eds.), Suomalaisten hyvinvointi 2018 [The Welfare of the Finns 2018] (pp. 6378). Helsinki: National Institute for Health and Welfare.

Kemppainen, T., Lönnqvist, H., \& Tuominen, M. (2014). Turvattomuus ei jakaudu tasan. Mitkä asuinalueen piirteet selittävät helsinkiläisten kokemaa turvattomuutta [Unsafety is not evenly distributed. Which residential area characteristics explain 
experiences of unsafety in Helsinki]. Yhteiskuntapolitiikka [Social Policy], 79(1), 5-20.

Kleinhans, R., Priemus, H., \& Engbersen, G. (2007). Understanding social capital in recently restructured urban neighbourhoods: Two case studies in Rotterdam. Urban Studies, 44(5-6), 1069-1091. https://doi.org/10.1080/00420980701256047

Koistinen, K., Peura-Kapanen, L., Honkanen, K., \& Poikolainen, J. (2017). Asumisen arvostukset ja kiinnittyminen alueeseen - Asuinaluekokemuksia Espoosta ja Lahdesta [Living appreciations and place attachment - Experiences from Espoo and Lahti]. Yhdyskuntasuunnittelu [The Finnish Journal of Urban Studies], 55(1), 33-51.

Kroll, C. (2011). Different things make different people happy: Examining social capital and subjective well-being by gender and parental status. Social Indicator Research, 104(1), 157-177. https://doi.org/10.1007/s11205-010-9733-1

Kullberg, A., Timpka, T., Svensson, T., Karlsson, N., \& Lindqvist, K. (2010). Does the perceived neighborhood reputation contribute to neighborhood differences in social trust and residential wellbeing? Journal of Community Psychology, 38(5), 591-606. https://doi.org/10.1002/jcop.20383

Luhmann, M., Hofman, W., Eid, M., \& Lucas, R. (2012.) Subjective well-being and adaptation to life events: A meta-analysis. Journal of Personality and Social Psychology, 102(3), 592-615. https://doi.org/10.1037/a0025948

Luhmann, M., Hawkley, L., \& Cacioppo, J. (2014). Thinking about one's subjective wellbeing: Average trends and individual differences. Journal of Happiness Studies, 5(4), 757-781. https://doi.org/10.1007/s10902-013-9448-5

Madill, A. (2011). Interaction in the semi-structured interview: A comparative analysis of the use of and response to indirect complaints. Qualitative Research in Psychology, 8(4), 333-353. https://doi.org/10.1080/14780880903521633

Margolis, R., \& Myrskyla, M. (2013). Family, money and health. Regional differences in the determinants of life satisfaction over the life course. Advances in Life Course Research, 18(2), 115-126. doi:10.1016/j.alcr.2013.01.001

Mellander, C., Florida, R., \& Stolaric, K. (2011). Here to stay - the effects of community satisfaction on the decision to stay. Spatial Economic Analysis, 6(1), 5-24. https://doi.org/10.1080/17421772.2010.540031

Metteri, A. (2012). Hyvinvointivaltion lupaukset, kohtuuttomat tapaukset ja sosiaalityö [Promises of a welfare state, non-fulfilment of these promises and social work]. Tampere: University of Tampere.

Permentier, M., Bolt, G., \& van Ham, M. (2011). Determinants of neighbourhood satisfaction and perception of neighbourhood reputation. Urban Studies, 48(5), 977-996. https://doi.org/10.1177/0042098010367860

Pontin, E., Schwannauer, M., Tai, S., \& Kinderman, P. (2013). A UK validation of a general measure of subjective well-being: The modified BBC subjective wellbeing scale (BBC-SWB). Health and Quality of Life Outcomes, 11(1), 1-9. https://doi.org/10.1186/1477-7525-11-150

Rasinkangas, J. (2013). Sosiaalinen eriytyminen Turun kaupunkiseudulla. Tutkimus asumisen alueellisista muutoksista ja asumispreferensseistä [Social segregation in the Turku Area. Research on regional changes and living preferences]. Siirtolaisinstituutti, Tutkimuksia A 43. [Institute of Migration, Research A 43] 
Roulston, K. (2011). International Journal of Qualitative Research, 10(4), 348-366. https://doi.org/10.1177/160940691101000404

Runge, J. (2018). Region-city-social space as key conceps of socio-economic geography. Environmental \& Socio-economic Studies, 6(3), 13-18. https://doi.org/10.2478/environ-2018-0018

Samuel, R., \& Hadjar, A. (2015). How welfare-state regimes shape subjective well-being across Europe. Social Indicators Research, 129(2), 565-587. https://doi.org/10.1007/s11205-015-1125-0

Scannell, L., \& Gifford, R. (2010). Defining place attachment: A tripartite organizing framework. Journal of Environmental Psychology, 30(1), 1-10. https://doi.org/10.1016/j.jenvp.2009.09.006

Seppänen, M., Haapola, I., Puolakka, K., \& Tiilikainen, E. (2012). Takaisin Liipolaan. Lähiö fyysisenä ja sosiaalisena asuinympäristönä [Back to Liipola. Suburb as physical and social residential environment]. Helsinki: Ympäristöministeriön raportteja 14/2012. [Ministry of the Environment, Reports 14/2012]

Statistics Finland. (2015a). Income and consumption. Retrieved from http://www.stat.fi/tup/suoluk/suoluk_tulot_en.html

Statistics Finland. (2015b). Open data by postal codes. Main type of activity 2012. Retrieved from http://pxnet2.stat.fi/PXWeb/sq/e1d45a3e-abbb-4da1-b55ca0e1c8cf0fa5

Strange, C., Fisher, C., Howat, P., \& Wood, L. (2014). The essence of being connected: The lived experience of mothers with young children in newer residential areas. Community, Work \& Family, 17(4), 486-502. https://doi.org/10.1080/13668803.2014.935704

Taylor, L., Hahs, A., \& Hochuli, D. (2018). Wellbeing and urban living: Nurtured by nature. Urban Ecosystems, 21(1), 197-208. https://doi.org/10.1007/s11252-017-0702-1

TILDA. (2015). Tilastotietoa Lahdesta [TILDA statistics from the city of Lahti]. Retrieved from http://www4.lahti.fi/verkkotilastointi/

Vaattovaara, M., \& Kortteinen, M. (2015). Segregaation aika [The age of segregation]. Yhteiskuntapolitiikka [Social Policy], 80(6), 562-574.

Vaattovaara, M., \& Kortteinen, M. (2012). Segregaatiosta ja sen inhimillisestä ja yhteiskunnallisesta merkityksestä [Segregation and its human and social significance]. Talous \& yhteiskunta [Economy and Society], 3, 60-66.

Vaismoradi, M., Turunen, H., \& Bondas, T. (2013). Content analysis and thematic analysis: Implications for conducting qualitative descriptive study. Nursing \& Health Sciences, 15(3), 398-405. https://doi.org/10.1111/nhs.12048

Vilkama, K., \& Vaattovaara, M. (2015). Keskiluokka kuin kotonaan? Kokemuksia sosioekonomisesti heikommilla alueilla asumisesta pääkaupunkiseudulla [Feeling at home? Middle class residents' experiences of living in socioeconomically disadvantaged areas in the Helsinki Metropolitan Area]. Yhteiskuntapolitiikka [Social Policy], 80(3), 207-220.

Völker, S., \& Kistemann, T. (2015). Developing the urban blue. Comparative health responses to blue and green open spaces in Germany. Health \& Place, 35, 196201. https://doi.org/10.1016/j.healthplace.2014.10.015

Wouter, P., van Gent, M., \& Ostendorf, W. (2009). Disentangling neighbourhood problems: Area-based interventions in Western European cities. Urban Research \& Practice, 2(1), 53-67. https://doi.org/10.1080/17535060902727066 